\title{
Mediastinal Germ Cell Tumor
}

National Cancer Institute

\section{Source}

National Cancer Institute. Mediastinal Germ Cell Tumor. NCI Thesaurus. Code C6437.

A germ cell tumor that arises from the mediastinum. Representative examples include seminoma, embryonal carcinoma, yolk sac tumor, teratoma, and mixed germ cell tumor. 